\title{
ANALISIS KETERAMPILAN MENULIS CERITA DENGAN METODE GUIDE WRITING KELAS III SDN KARANG TENGAH 2 KOTA TANGERANG
}

\author{
Aulia Eka Saputri ${ }^{1}$, Yeni Nuraeni ${ }^{2}$, Dilla Fadhillah ${ }^{3}$ \\ Universitas Muhammadiyah Tangerang, Kota Tangerang \\ Auliaeka48@gmail.com, yeniyayang1973@gmail.com, dillafadhillah89@gmail.com
}

\begin{abstract}
ABSTRAK
Keterampilan menulis cerita dengan Guide Writing, penelitian ini bertujuan untuk mengetahui keterampilan menulis siswa dengan metode Guide Writing di kelas III Sekolah Dasar dengan adanya tujuan ini dapat mengetahui tercapainnya tujuan pada penelitian ini. Metode penelitian ini digunakan metode kualitatif, yang di dapatkan dengan mendeskripsikan hasil dari penelitian pada siswa kelas III. Subjek yang digunakan untuk penelitian yaitu siswa kelas III di SD tersebut. Teknik pengumpulan data pada peenlitian ini digunakan yaitu tes, observasi dan dokumentasi. Maka hal ini peneliti menperoleh informasi dan hasil penelitian terhadap keterampilan menulis siswa dengan metode Guide Writing. Yang dimana sudah cukup baik dalam keterampilan menulis pada siswa kelas III, dan sudah cukup baik terhadap penilaian tentang menulis dengan metode tersebut, dengan point Mengenalkan jenis teks dengan memberi model paragraf, memahami isi teks dengan pertanyaan pemahaman, berlatih menggunakan tata bahasa dan kosa kata yang benar dengan latihan berbasis bahasa, menghasilkan gagasan dan merevisi kesalahan siswa dengan komposisi lisan dan, mengembangkann gagasan dan berlatih menulis nyata dengan komposisi tertulis. Hanya saja ada beberapa siswa yang mendapatkan penilaian di bawah rata-rata pada proses pembelajaran hingga penilaian pada menulis cerita. Maka dengan adanya pembelajaran dapat menambah peningkatan pada proses pembelajaran menulis cerita yang proses pembelajarannya terbimbing. Pada peningkatan point penilaian pertama mencapai $41,7 \%$, pada point penilaian kedua mencapai $66,7 \%$, pada point penilaian ketiga mencapai $58,3 \%$, pada point penilaian keempat mencapai 33,3\% pada point penilaian terakhir yaitu yang ke lima mencapai $62,5 \%$. Maka pada peningkatan ini belum begitu baik yang dilakukan oleh siswa kelas III sekolah dasar dalam membuat cerita dengan metode Guide Writing.
\end{abstract}

Kata kunci: Keterampilan Menulis Cerita, Metode Guide Writing, kualitatif

\begin{abstract}
Story writing skills with Guide Writing, this study aims to determine students' writing skills using the Guide Writing method in grade III Elementary School. This research method used qualitative methods, which were obtained by describing the results of research on third grade students. The subjects used for the study were third grade students at the elementary school. Data collection techniques in this study were used, namely tests, observations and documentation. So, the researchers obtained information and research results on students' writing skills using the Guide Writing method. Which is quite good in writing skills for third grade students, and is good enough in assessing writing with this method, with the points Introducing the type of text by giving a paragraph model, understanding the content of the text with comprehension questions, practicing using grammar and vocabulary. correct with language-based exercises, generate ideas and revise students' mistakes with oral compositions and, develop ideas and practice real writing with written compositions. It's just that there are some students who get below average assessments in the learning process to assessments on writing stories. So with the learning can add to the improvement in the learning process of writing stories that the learning process is guided. In the first assessment point increase it reached $41.7 \%$, in the second assessment point it reached $66.7 \%$, in the third assessment point it reached $58.3 \%$, in the fourth assessment point it reached $33.3 \%$ in the last assessment point, namely the fifth it reached $62,5 \%$. So in this improvement, the third grade elementary school students have not done well in making stories using the Guide Writing method.
\end{abstract}

Keywords: Story Writing Skills, Guide Writing Method, qualitative 


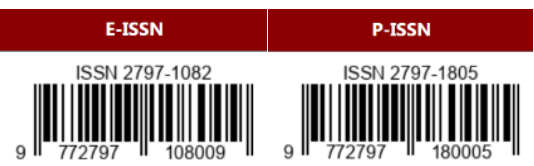

\section{PENDAHULUAN}

Pendidikan merupakan sebagai usaha sadar dan terencana untuk mewujudkan suasana belajar dan proses pembelajaran untuk peserta didik secara aktif mengembangkan potensi dirinya untuk memiliki kekuatan spiritual keagamaan, pengendalian diri, kepribadian, kecerdasan, akhlak mulia, serta keterampilan yang diperlukan dirinya dan masyarakat. Dalam Undang Undang RI nomor 2 tahun 1989 tentang sistem pendidikan nasional, disebutkan bahwa pendidikan adalah usaha sadar untuk menyiapkan peserta didik melalui kegiatan bimbingan, pengajaran, dan latihan bagi peranannya di masa yang akan datang. Pendidikan nasional berfungsi untuk mengembangkan kemampuan serta meningkatkan mutu kehidupan dan martabat manusia Indonesia dalam rangka mewujudkan nasional.

Pendidikan tercantum dalam UU No. 20 Tahun 2003 tentang SISDIKNAS, yakni: pendidikan adalah salah satu faktor penting untuk mengembangkan potensi-potensi siswa. Pendidikan merupakan pengetahuan, keterampilan, sikap dan kebiasaan yang diajarkan oleh seorang pengajar ke peserta didik agar peserta didik memiliki kecerdasan akhlak yang baik, kepribadian serta keterampilan yang berguna bagi diri sendiri, masyarakat, bangsa dan negara.

Pembelajaran bahasa Indonesia di sekolah dasar memiliki peranan yang begitu sangat strategis mengingat bahwa tujuannya yaitu memberikan bekal kemampuan dasar baca, tulis, dan hitung yang dapat bermanfaat untuk siswa sesuai dengan tingkat perkembangannya. Dalam dunia pendidikan terdapat empat keterampilan berbahasa yang yang harus dikuasai, yaitu: keterampilan berbicara, keterampilan menyimak, keterampilan membaca dan keterampilan menulis. Keempat keterampilan tersebut merupakan keahlian terapan yang saling berkaitan satu dengan yang lainnya.

Keterampilan Berbicara merupakan salah satu perkembangan bahasa yang dikembangkan pada anak usia dini sebagai sarana komunikasi dan sarana untung mengungkapkan yang dirasa. Dalam hal ini keterampilan berbicara yang dilakukan oleh peserta didik kelas III SDN Karang Tengah 2 dapat berjalan dengan baik dan tidak ada yang keterbatasan atau kesulitan dalam berbicara dengan sesama peserta didik maupun dengan Guru. Keterampilan berbicara yang dilakukan di SD tersebut bisa dibilang sudah lumayan bagus. Hanya saja ada beberapa siswa yang sulit berbica dikarnakan malu dengan teman dan guru.

Keterampilan menulis terdapat dalam mata pelajaran Bahasa Indonesia. Kegiatan menulis sangat penting dalam melatih siswa menuangkan dan menggambarkan ide-ide, pengalaman, serta kemampuan dalam berfikirnya ke dalam bentuk tulisan. Secara umum tulisan di kembangkan dalam beberapa bentuk yaitu, deskriptif, narasi, eksposisi, persuasi dan argumentasi. Salah satunya menulis cerita yang merupakan pengungkapan ide dan gagasan pada orang lain melalui kegitan menulis cerita.

Dengan menggunakan metode Guide Writing merupakan suatu cara yang tepat untuk membantu siswa dalam pembelajaran bahasa Indonesia khususnya menulis cerita. Teknik Guide Writing atau menulis terbimbing merupakan suatu cara atau petunjuk yang yang digunakan pengajar secara sistematis dalam membimbing siswa untuk menuangkan ide atau gagasan secara tertulis. Pada peserta didik kelas III di SDN Karang Tengah 2 merasa mudah dalam menulis cerita di karenakan peserta didik terbimbing dalam melaksanakan penulisan 


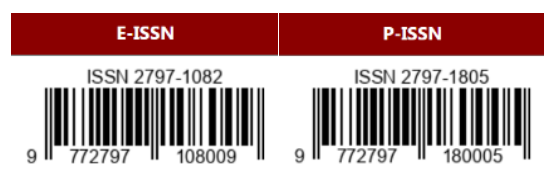

tersebut. Sehingga memudahkan peserta didik dalam menuangkan ide-ide yang mereka pikirkan untuk di jadikan sebuah cerita yang akan mereka tulis dan kembangkan.

Dari hasil data observasi awal yang ditemui di kelas III Sekolah Dasar yaitu mengalami permasalahan pada pembelajaran menulis cerita. Tentang bagaimana siswa dapat menuangkan ide-ide yang akan mereka kembangkan dan keterampilan dalam menulis menjadi cerita. Hal ini disebabkan kurangnya media gambar yang bermacam macam, warna dan bentuk yang tidak menarik yang menyebabkan peserta didik tidak dapat sepenuhnya mengembangkan ide-ide kreatifnya dalam sebuah cerita. Dan juga masik cukup banyak peserta didik yang hanya menulis cerita dengan singkat dan menggunakan kosakata yang tidak baku.

Permasalahan yang ditemui tersebut dapat diatasi dengan pengajar lebih memperbanyak gambar dan warna yang menarik yang akan diberikan kepada siswa tersebut. Agar siswa dapat menuangkan dalam sebuah cerita dan menjelaskan perihal kosakata yang baku untuk mempermudah jalannya pembelajaran tersebut. Guru juga harus menyiapkan bahan yang menarik agar dapat menarik siswa dalam pembelajaran. Berdasarkan latar belakang di atas maka peneliti tertarik untuk melakukan penelitian dengan judul "Analisis Keterampilan Menulis Dengan Metode Guide Writing Kelas III SDN Karang Tengah 2 Kota Tangerang"

\section{LANDASAN TEORI}

Menurut Pranowo (2019) kemampuan menulis merupakan kemampuan mengungkapkan gagasan menggunakan bahasa tulis (h.255). Dengan menulis dapat melatih keterampilan menulis seseorang dengan benar. Keterampilan menulis dapat membantu seseorang untuk menuangkan ideide yang ada dalam bentuk karya tulis. Dengan keterampilan menulis seseorang dapat menciptakan hasil karya tulisan seperti buku.

Dalam pemebelajaran tulisan dapat berperan penting saat proses pembelajaran. Tulisan dapat digunakan untuk menyampaikan suatu informasi dengan menggunakan media atau bahan tulisan. Tulisan juga dapat digunakan dalam kegiatan sehari-hari ketika ingin bercerita atau menulis cerita. Dalam kegitan menulis cerita tulisan sangat diperlukan untuk memaksumalkan pembelajaran seperti pembelajaran bahasa Indonesia yang dimana pengguaan tulisan dapat melancarkan kegitan belajar tersebut.

Penjelasan tulisan dapat ditinjau dari berbagai segi, antara lain berdasarkan keobjektifan masalah dan berdasarkan isi dan sifatnya. Menurut Nurjamal, dkk (2019) berdasarkan keobjektifan masalahnya tulisan dapat dibedakan menjadi tiga jenis yakni: (1) Tulisan ilmiah, (2) Tulisan populer, (3) Tulisan fiktif (h.69).

Unsur merupakan suatu macam sebagai sarana. Unsur menulis dalam pembelajaran dapat dijadikan sebgaisarana berkomunikasi antara guru dengan siswa. Unsur juga dapat dijadikan pesan atau isi tulisan yang akan digunakan dalam pembelajaran berlangsung. Dengan adanya unsur guru dan siswa mudah menerima suatu pesan atau informasi.

Seperti keterampilan lainya menulis juga memiliki manfaat yang sangat banyak menurut Fadhillah, dkk (2019) terdapat delapan manfaat menulis di bawah ini:

(1) Dengan menulis seorang dapat mengetahui potensi pengetahuan yang mereka miliki tentang topik bahasa tertentu.

(2) Dengan menulis kemampuan menulis nalar seorang akan terasah. 


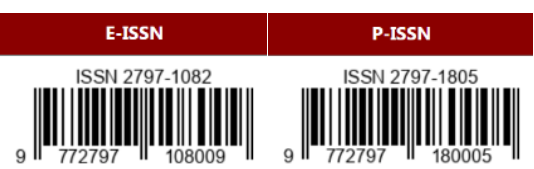

(3) Menulis merupakan suatu cara untuk melatih seseorang memperluas wawasan, karena dengan menulis pastilah seorang harus mencari informasi yang akurat untuk ditulis.

(4) Menulis dapat membuat seseorang tersebiasa melakukan sesuatu dengan sistematis.

(5) Seorang menulis dapat menilai dengan objektif tulisannya sendiri apakah sudah layak atau belum dengan cara berkali kali dibaca.

(6) Seorang penulis akan lebih mudah menganalisa sebuah masalah secara tertulis dan memiliki bukti fisik tulisan dari pada dalam bentuk lisan.

(7) Melalui tulisan seseorag akan selalu aktif dalam berfikir yang sangat bermanfaat untuk menjaga ingatan, bahkan seseorang penulis juga bisa menjadi penemu karena kedasyatan pemikirnya.

(8) Kegiatan menulis yang terencana akan membiaskan kita hidup dengan pola yang terencana, dan bertata bahasa yang baik pula (h.54-55).

Menurut Fadhillah (2019) terdapat proses atau tahap tahap dalam menulis seperti di bawah ini:

\section{Pramenulis}

Pramenulis merupakan tahapan persiapan. Pada tahapan ini seseorang penulis melakukan berbagai kegiatan, misalnya, menemukan ide gagasan, menentukan judul karangan, menentukan judul, memilih bentuk atau jenis tulisan, membuat kerangka, dan mengumpulkan bahan-bahan.

\section{Saat Menulis}

Tahapan penulisan dimulai dengan menjabarkan ide kedalam bentuk tulisan. Ideide itu dituangkan dalam bentuk kalimat dan paragraf. Selanjutnya paragraf itu dirangkai menjadi satu karangan yang utuh. Tahap ini memerlukan berbagai pengetahuan kebhasaan dan tekni penulisan.

\section{Pascamenulis}

Pascamenulis terdiri dari tiga, yaitu: (a) Merevisi atau mengubah; (b) Mengedit; (c) Menyajikan atau mempublikasikan tulisan.

Menurut Fauziddin (2017) cerita merupakan media paling tepat untuk untuk menyampaikan pelajaran kepada anak-anak, karena melalui media ini si pembawa cerita dapat mengajak anak untuk membayangkan perilaku seseorang menjadi tokoh idola dan menjadi panutan (h.17).

Menurut Milaningrum, dkk (2017) metode Guide Writing adalah kegiatan individu atau kelompok dari proses menulis yang dipandu oleh guru, dimana peserta didik menggunakan model tulisan, tanya jawab, peta kata untuk mengatur ide-ide, dan latihan berbasis bahasa yang dikhususkan untuk membangun kosa kata, pemahaman bacaan, tata bahasa dan keterampilan bahas lisan yang pada akhirnya membentuk sebuah tulisan (h.366).

\section{METODE PENELITIAN}

Dalam penelitian ini menggunakan pendekatan kualitatif, dalam penelitian ini menggunalam penelitian kualitatif deskriptif. Penelitian ini dilakukan dengan berdasarkan temuan dilapangan mengenai suatu gambaran apa adanya yang terjadi di lapangan. Agar penelititi dapat mendeskripsikan secara jelas dan rinci serta mendapat dalam mendalam mengenai "Analisis Keterampilan Menulis Dengan Metode Guide Writing Kelas 3 SDN Karang Tengah 2". Hal ini sangat diutamakan dalam penelitian kualitatif yang mengungkapkan suatu data dan informasi yang dapat ditarik makna dan konsep. 


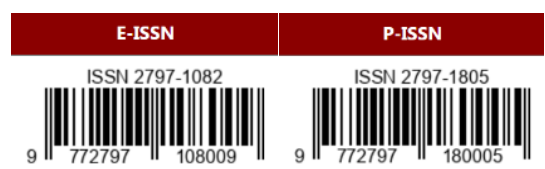

Menurut Moleong (2014) penelitian kualitatif adalah penelitian yang menghasilkan prosedur analisis yang tidak menggunakan prosedur analisis statistik atau cara kuantifikasi lainnya (h.6). Penelitian ini bertjuan mendapatkan masalah yang akan dideskripsikan oleh seseorang pada suatu masalah. Untuk mendapat menjadi suatu instumen maka peneliti mempunyai bekal teori dan wawasan untuk meneliti sehingga mampu menganalisis suatu penelitian yang ada. Penelitian ini dilakukan dengan objek alamiah yang dimana objek tersebut akan peneliti analisis untuk menemukan hasil atau data. Tujuan dari penelitian ini untuk mengetahui kemampuan menulis cerita dengan metode Guide Writing siswa kelas 3 SD Negri Karang Tengah 2. Dalam data penelitian ini diperoleh dengan menggunakan instrumen penelitian berupa tes, observasi, dokumentasi.

Teknik pengumpulan data sebagai langkah paling utama dalam penelitian karena tujuan utama dalam penelitian. Karena tujuan utama pengumpulan data adalah mendapatkan data dari sumber data. Karena tanpa menggunakan teknik pengumpulan data peneliti tidak dapat menemukan data yang standar yang sudah ditetapkan. Teknik pengumpulan data dapat dilakukan dalam berbagai sumber dan cara seperti observasi, wawancara, dokumentasi.

\section{HASIL DAN PEMBAHASAN}

Penelitian ini dimaksud untuk mengetahui keterampilan menulis cerita dengan metode Guide Writing yang dimana hasil dari penelitian yang telah peneliti lakukan yaitu terdapat 10 siswa yang mendapatkan penilaian dibawah rata-rata dari 24 murid keseluruhan di SD tersebut.

Berdasarkan pada data yang ada merupakan data seluruh siswa yang melakukan tes tersebut. Dari nama-nama yang ada sesuai dengan penilaian dan cara pengerjaan masing-masing siswa kelas III dalam keterampilan menulis cerita dengan metode Guide Writing yang dilakukan oleh penenliti di kelas tersebut. Dalam pelaksanaan tes menulis ini kurangnya pemahaman tentang memebuat paragraf yang baik dan benar, belum tepatnya penempatan tanda baca pada sebuah kalimat. Dalam pelaksanaan tes tersebut siswa diminta untuk membuat cerita dengan point-point yang ada melaikan masih belum maksimal atau masih ada yang tidak paham. Yang dimana dalam pelaksanaan tes ini untuk mengetahui pemahaman atau keteramoilan siswa kelas III dalam menulis sebuah cerita dengan metode Guide Writing.

\section{KESIMPULAN DAN SARAN Kesimpulan}

Berdasarkan hasil penelitian tentang keterampilan menulis dengan metode Guide Writing kelas III SDN Karang Tengah 2 Kota Tangerang. Pemahaman menulis dengan metode ini seharusnya mudah dipahamin oleh siswa kelas III sekolah dasar, namun yang terdapat pada penelitian ini ada beberapa siswa yang tidak dapat memahami atau mengerti tentang metode tersebut. Maka dapat diperoleh beberapa kesimpulan dibawah ini sebagai berikut:

Penelitian dengan metode Guide Writing pemahaman siswa pada saat pembelajaran dan mengerjakan tugas masih kurang baik dikarenakan pembelajaran yang dilakukan secara online atau daring. Dari hasil tes keterampilan menulis cerita siswa ditemukan kurangnya pemahaman tentang paragraf yang benar,dan penempatan tanda baca seperti (.) masih kurang tepat. Sehingga menyebabkan siswa kurangnya menungkan ide-ide dalam menulis cerita dikarenakan kurang mengerti atau kurangnya pemahaman 
pada saat penjelasan yang diberikan oleh guru secara online. Beda halnya ketika pembelajaran dilakukan secara langsung atau tatap muka, guru yang menerangkan juga mudah dalam menjelaskan tentang pembelajaran yang sedang siswa pelajari.

Pada saat proses pembelajaran menggunakan metode Guide Writing pada peningkatan kinerja atau penugasan yang sudah siswa buat masih kurang baik dalam peningkatan menulis cerita dengan metode tersebut. Walaupun metode tersebut dilakukan dengan cara terbimbing oleh guru. Pada peningkatan point penilaian pertama mencapai $41,7 \%$, pada point penilaian kedua mencapai $66,7 \%$, pada point penilaian ketiga mencapai $58,3 \%$, pada point penilaian keempat mencapai $33,3 \%$ pada point penilaian terakhir yaitu yang ke lima mencapai $62,5 \%$. Maka pada peningkatan ini belum begitu baik yang dilakukan oleh siswa kelas III sekolah dasar dalam membuat cerita dengan metode Guide Writing.

\section{Saran}

Berdasarkan kesimpulan diatas maka saran yang dapat disampaikan oleh peneliti untuk beberapa pihak sebagai berikut:

\section{Bagi guru}

Diharpakan supaya lebih bisa memfokuskan siswa ketika pembelajaran, dapat memaksimalkan penggunaan metode dalam keterampilan menulis cerita dan penggunaan media gambar dalam metode ini agar dapat menarik perhatian siswa dalam pembelajaran. Melaikan pembelajaran saat ini dilakukan secara online bagaimana guru lebih memfokuskan siswa untuk pemahaman ketika pembelajaran.

\section{Bagi siswa}

Dapat diharapkan lebih fokus dalam pembelajaran dan memahami penjelasan yang disampaikan guru kelas, dan lebih bisa memahami tentang metode tersebut, seperti cara menyusun atau membuat paragraf yang baik dan benar, serta penempatan tanda baca yang baik dan benar.

\section{Bagi Sekolah}

Peneliti harap sekolah lebih mensuport tentang metode-metode yang akan guru gunakan untuk proses pembelajaran, supaya dapat melatih siswa dalam pemebelajaran yang berlangsung.

\section{Bagi Peneliti}

Untuk penelitian ini yang peneliti harapkan yaitu dapat mempelajari lebih lanjut tentang metode tersebut, bilamana dapat diterapkan ketika peneliti sudah terjun langsung menghadapi kelas dan dapat menjelaskan dengan baik dan mempermudah proses pembalajaran agar siswa lebih bisa menguasai dalam belajar.

\section{DAFTAR PUSTAKA}

Fadhillah, D. Hamsanah, S.H. dan Latifah, N. (2019). Pembelajaran Bahasa Indonesia Kelas Tinggi. Yogyakarta: Samudra Biru.

Fauziddin, M. (2017). Pembelajaran Paud, Cet-3. Bandung: PT REMAJA ROSDAKARYA.

Jayadi, U. (2021). Penerapan Metode Pembelajaran Cooperative Integrated Reading And Composition (Circ) Untuk Meningkatkan Hasil Belajar Dalam Menemukan Kalimat Utama Pada Siswa Kelas IV SDN 22 Mataram Tahun Pelajaran 2020/2021. Berajah Journal, $\quad 1(1), \quad 21-42$. https://doi.org/10.47353/bj.v1i1.17

Milaningrum, E. Damayanti, L. Gafur, Abdul. (2017). Menerapkan Guide Writing Pada Teks Narasi Untuk Meningkatkan 
Writing Skill Mahasiswa

Politeknik Negeri Balikpapan.

SNITT- Politeknik Negeri Balikpapan

2017 ISBN:978-602-51450-01.

JurnalOnline:

https://jurnal.poltekba.ac.id/index.php/

prosiding/article/view/422. Diakses

pada: 9 Maret 2021 Jam 11: 09.

Moleong, Lexy J. (2014). Metodologi

Penelitian Kualitatif, Cet-33. Bandung:

PT REMAJA ROSDAKARYA.

Nurjamal, D. Sumirat, W. Darwis, R. (2019).

Terampil Berbahasa. Bandung: Penerbit

Alfabeta.

Pranowo. (2019). Teori Belajar Bahasa.

Yogyakarta: Pustaka Pelajar.

Riinawati, R. (2021). Hubungan Penggunaan

Model Pembelajaran Blended Learning

terhadap Hasil Belajar Matematika

Siswa Sekolah Dasar. EDUKATIF:

JURNAL ILMU PENDIDIKAN, 3(6), 3794-3801.

Riinawati, Riinawati. (2021). Education Financial Management during Covid-19 Pandemic of Islamic Universities in South Kalimantan. Dinamika Ilmu, 21(2), 383-396.

https://doi.org/10.21093/di.v21i2.3607 